\title{
Tyrosine kinase inhibitor treatment outcome in a single center cohort of chronic myeloid leukemia patients. The role of the T315I ABL kinase domain mutation
}

\author{
Rezultatele tratamentului cu inhibitori de tirozin-kinaze pe un lot de \\ pacienți cu leucemie mieloidă cronică. Rolul mutației T315I a \\ domeniului kinazic ABL
}

\author{
Delia Dima ${ }^{1}$, Adrian P. Trifa ${ }^{2}$, Mariana Paţiu ${ }^{1}$, Cristian S. Vesa ${ }^{3}$, Ioana C. Frinc ${ }^{1}$, \\ Ljubomir Petrov ${ }^{1}$, Andrei Cucuianu ${ }^{1 *}$ \\ 1. "Ion Chiricuța" Cancer Institute Cluj-Napoca, Hematology Department \\ 2. University of Medicine and Pharmacy "Iuliu Hațieganu" Cluj-Napoca, Genetics Department \\ 3. University of Medicine and Pharmacy "Iuliu Hațieganu" Cluj-Napoca, Medical Pharmacology \\ Department
}

\begin{abstract}
Introduction. Since the introduction of the tyrosine kinase inhibitor (TKI) imatinib mesylate (IM) in the treatment of chronic myeloid leukemia $(C M L)$, a dramatic improvement in hematologic, cytogenetic and molecular responses was noted. Also, the overall survival increased significantly. Unfortunately, in certain patients, resistance to TKI develops relatively early, especially due to point mutations in the ABL kinase domain, among which the T315I mutation confers resistance to all three currently available TKIs (imatinib, dasatinib, nilotinib). Methods. We performed a prospective study on 74 patients diagnosed with chronic phase CML, for whom we analyzed the T315I mutation. Mutational analysis was performed using ARMS-PCR (with subsequent confirmation by direct sequencing) at regular intervals of 6 months or in case of suboptimal response, loss of response or progression. Correlations between the T315I mutation and disease characteristics, response to treatment and survival were analyzed. A comparative analysis between patients positive and negative for the mutation was performed. The patients were followed and evaluated according to European Leukemia Net (ELN) criteria. Results. T315I mutation was detected in 3 patients $(4.05 \%)$ and its presence was correlated with younger age at diagnosis, second line TKI therapy, progressive disease and decreased survival from the moment of detection. Conclusions. ARMS-PCR is a sensitive, easy to use method for the detection of T315I mutation in chronic phase CML patients.
\end{abstract}

Keywords: Chronic myeloid leukemia, mutation, T315I, imatinib

\footnotetext{
*Corresponding author: Andrei Cucuianu, "Ion Chiricuta"Cancer Institute, Hematology Department, 73, 21 Decembrie 1989 Bvd, 400124, Cluj-Napoca. Email: acucuianu@yahoo.com
} 


\section{Rezumat}

De la introducerea inhibitorului de tirozinkinază (ITK) imatinib mesylate (IM) în terapia leucemiei mieloide cronice (LMC), s-a observat o îmbunătăţire dramatică a răspunsului hematologic, citogenetic şi molecular. Din păcate, la o parte din pacienți, a apărut şi rezistența la ITK, în special datorată mutațiilor punctiforme ale kinazei ABL, dintre care mutația T315I conferă rezistență la toți cei 3 ITK disponibili în prezent (imatinib, dasatinib, nilotinib). Am efectuat un studiu prospectiv pe un lot de 74 pacienți diagnosticați cu LMC fază cronică, la care am urmărit apariția mutației T315I. Analiza mutațională a fost efectuată utilizând tehnica ARMS-PCR, (confimată prin secvențiere directă în caz de pozitivitate) la interval regulat de 6 luni sau în condiții de lipsă de răspuns la tratament, de pierdere a răspunsului sau în caz de evoluție a bolii. Am urmărit corelații între prezența mutației, caracteristici ale bolii şi răspunsul la tratament, precum şi supraviețuirea la aceşti pacienți. Am efectuat o analiză comparativă între pacienții cu mutație T315I şi cei fără mutație. Urmărirea pacienților şi evaluarea răspunsului s-au făcut conform criteriilor European Leukemia Net (ELN). Mutația T315I a fost decelată la 3 pacienți (4.05\%) prezența ei corelându-se cu vârsta tânară la debut, cu utilizarea a două linii de ITK, cu boala progresivă şi supraviețuire de scurtă durată de la apariția mutației. Tehnica ARMS-PCR este o metodă sensibilă, uşor de utilizat în detectarea mutaţiei T315I la pacienții cu LMC fază cronică.

Cuvinte cheie: leucemie mieloidă cronică, mutație, T315I, imatinib

Received: $29^{\text {th }}$ November 2012; Accepted: 13 $3^{\text {th }}$ February 2013; Published: $25^{\text {th }}$ February 2013.

\section{Introduction}

Chronic myeloid leukemia (CML) is a clonal disease of the hematopoietic pluripotent stem cell, characterized by the presence of the Philadelphia chromosome $\left(\mathrm{Ph}^{1}\right)$ and/or the BCRABL transcript, probably one of the most intensively and comprehensively studied malignancies (1). Since the introduction of imatinib mesylate (IM) in 1999 as the first tyrosine kinase-targeted molecule, a significant improvement in hematologic, cytogenetic and molecular responses was noted, as well as an increase in overall survival, IM being considered the most important progress made in the last 25 years in oncology (2). Nowadays, the life expectancy in most newly diagnosed CML patients approaches that of the general population. Unfortunately, the initial enthusiasm was soon darkened by the appearance in some patients of resistance to IM. The most frequent and profoundly studied mechanism of resistance is the emergence of point mutations of the ABL kinase domain (3). Several multicenter studies showed that approximately $37 \%$ of patients treated with IM will have a suboptimal response or fail IM treatment, a significant proportion of these failures being due to point mutations $(4,5)$.
Identifying as early as possible those patients allows early therapeutic strategy change. It is known that once the disease progresses, the response rate is reduced despite the introduction of the second generation tyrosine kinase inhibitors (TKI), nilotinib and dasatinib $(4,5)$. Among the more than 100 known BCR-ABL point mutations, the T315I mutation confers resistance to all the three currently available TKIs and to other drugs as well. The mutation results from threonine replacement with isoleucine at position 315 , thus preventing the hydrogen bound formation between IM, nilotinib or dasatinib and the kinase (4). Several studies have shown that T315I mutation is associated with reduced survival and reduced progression free survival (6- 8). The T315I mutation represents $11-20 \%$ of all mutations detected in patients resistant to IM in all phases chronic, accelerated and blastic $(6,7)$. T315I mutation was also detected, after treatment with $2^{\text {nd }}$ generation TKI, in $27 \%$ of patients treated with nilotinib and in $46 \%$ patients treated with dasatinib $(9,10)$. Recent studies showed good results with third generation TKI, especially ponatin$\mathrm{ib}$, but so far, the only certified treatment for patients bearing the T315I mutation is allogeneic marrow transplantation, a procedure still associ- 
ated with a high rate of morbidity and mortality (11). There is a good cost/benefit ratio for identifying these patients through mutational analysis. The cost of the analysis is merely a small part of the treatment's cost and identifying non responders allows to avoid unnecessarily expensive treatment and to switch to other strategies. Until recently, in Romania, mutational analysis was done only in one center, namely The Fundeni Hematology Clinic in Bucharest. In this study, we analyzed prospectively the presence of T315I mutation in chronic phase CML patients and its impact on response to therapy and prognosis.

\section{Patients and methods}

\section{Patients' characteristics}

There were 74 consecutive CML patients in chronic phase, 44 women and 30 men, with a median age of 51.5 years (18-84 years), diagnosed with chronic phase CML between 1996 and 2010, and treated with TKI therapy at the "Ion Chiricuța" Cancer Institute, Hematology Dept, Cluj-Napoca. All subjects were followed for at least 48 months.

The patients were classified according to the Sokal, Hasford and EUTOS risk scoring systems. The Sokal score was low for $26(35.1 \%)$ patients, intermediate for $25(33.8 \%)$ patients and high for $23(31.1 \%)$ patients. The Hasford score was low for $26(35.1 \%)$ patients, intermediate for $41(55.4 \%)$ patients and high for $7(9.5 \%)$ patients. The EUTOS score was 1 for 48 (64.9\%) patients and 2 for $26(35.1 \%)$ patients.

Median spleen size was $3 \mathrm{~cm}$ below costal margin (range $0-23 \mathrm{~cm}$ ). The median value for the white blood cell count (WBC) was $98.8 \times 10^{3} / \mu 1\left(10 \times 10^{3}-392 \times 10^{3} / \mu 1\right)$, for platelets (Plt) was $498.4 \times 10^{3} / \mu \mathrm{l}\left(115 \times 10^{3}-1907\right.$ $\left.\mathrm{x} 10^{3} / \mu \mathrm{l}\right)$ and for hemoglobin $(\mathrm{Hb}), 11.3 \mathrm{~g} / \mathrm{dl}(4-$ $20 \mathrm{~g} / \mathrm{dl}$ ). The LDH values were widely distributed with a median value of 717.5 U/L (300$2500 \mathrm{U} / \mathrm{L})$.

In all patients the typical $t(9 ; 22)$ (q34;q11) translocation (the Philadelphia chro- mosome, $\mathrm{Ph}^{1}$ ) was found at karyotyping. Four patients presented with additional chromosomal abnormalities: additional $\mathrm{Ph}^{1}$ in 2 patients; chromosome $\mathrm{Y}$ deletion in 1 patient; in 1 patient trisomy 8 and 16q deletion was found and hyperploidy was found in 1 patient. At rqPCR, all patients were positive for the BCR-ABL mutation, displaying the typical b3a2 transcript. Since 2009, rqPCR monitoring at 3-6 months became standard practice in our department.

\section{Treatment}

Fifty five patients $(74.3 \%)$ received imatinib mesylate (IM) as first line therapy. Median duration of treatment was 32.2 months (2109 months). Dasatinib was given to 11 (14.9\%) patients, as second line after IM. Median duration of therapy was 14.1 months (1-48 months). Nilotinib was administered in 18 (24.3\%) patients, among which 9 patients in first line. Median duration of treatment was 6.2 months (1- 24 months). Second generation TKI's were administered in most cases for lack of efficacy to first line. Treatments given prior to TKI included: hydroxiurea, initially administered in $66(89.2 \%)$ patients, mostly for the cytoreductive effect, interferon-alpha (IFN) in 20 (27\%) patients, cytarabine in $6(8,1 \%)$ patients, 6-mercapto purine (6-MP) in $4(5.4 \%)$ patients. Treatment type, response and duration before entering the study were also analyzed. Treatment response to TKI (hematological, cytogenetic and molecular) was assessed according to the criteria defined by European Leukemia Net (ELN).

\section{T315I mutation analysis}

T315I mutation analysis was done regulary at 6 months and at times of suboptimal response, loss of response or progression. ARMSPCR (amplification refractory mutation system polymerase chain reaction) was used for the detection of the T315I mutation. The first step consisted in extracting DNA using a Wizard Genomic DNA Purification (Promega, Madison, USA) extraction kit. Then DNA was amplified by PCR using 3 primers: the primer for normal allele: $5^{\prime}$ GCC CCC GTT CTA TAT CAT CAC-3', primer 


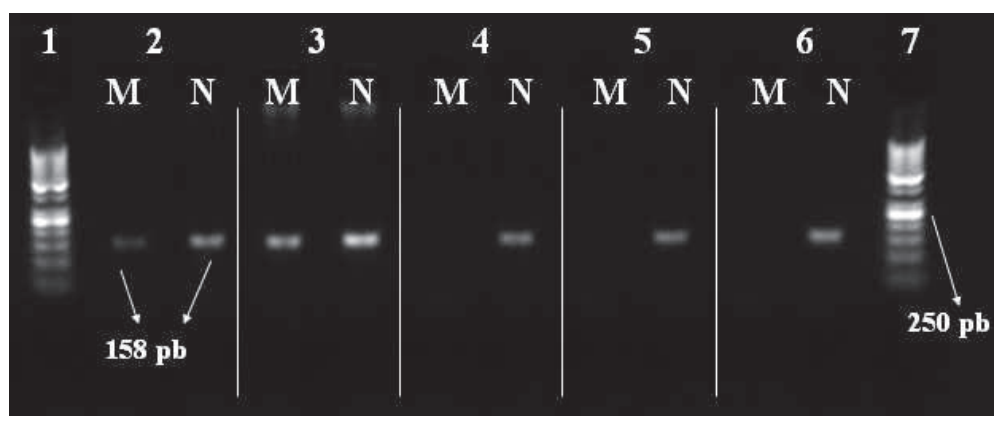

Figure 1. 2\% agarose gel electrophoresis (ARMS-PCR). 1, 7 - DNA marker with molecular weight $(50 \mathrm{pb}) .2,3$ - patients positive for T315I mutation. 4, 5, 6 -patients negative for T315I mutation. $\mathrm{N}$ - fragment specific to normal allele $(158 \mathrm{pb})$. $\mathrm{M}$ - fragment specific to mutant allele (158 pb).

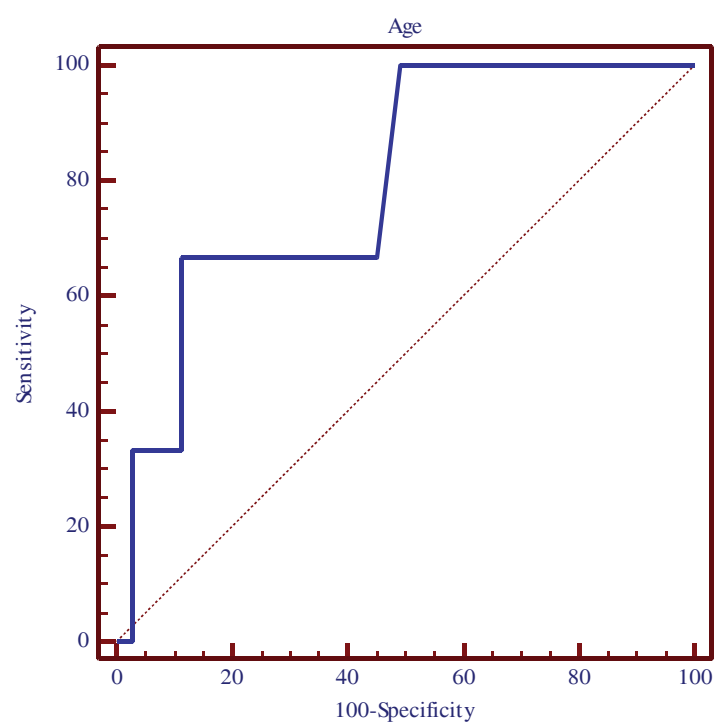

Figure 2. ROC curve for patients' age T315I mutation

for mutant allele: 5'- CCC GTT CTA TAT CAT CAT-3' and the common primer: 5'- GGA TGA AGT TTT TCT TCT CCA G-3'. Finally the DNA fragments obtained migrated through electrophoresis in $2 \%$ agarose gel, colored with ethidium bromide. Electrophoresis was done at a tension of $100 \mathrm{~V}$, for 30 minutes, in tampon 1xTBE. For visualizing the gels, we used an UV transiluminator, coupled with a photo documentation system (Vilber Lourmat, France) (12-15) (Figure 1). Positive samples were later confirmed in other centers by direct sequencing.

SPSS (Statistical Package for the Social Sciences) v20 and Medcalc v12.3 were used for statistical analysis. For univariate analysis, $\mathrm{T}$ test for independent variables and ANOVA test were used for variables with normal distribution, Mann- Whitney and Kruskall-Wallis tests were used for non-normal distributed variables, $\chi^{2}$ test was used for ordinal and dihotomic variables and log-rank test was used for time dependent variables.

\section{Results}

\section{Response to TKI treatment}

Complete hematologic response (CHR) after first line TKI was observed in 60 (90.9\%) patients. Three $(4.5 \%)$ patients had partial hematologic response, and another three patients $(4.5 \%)$ patients had no response. Complete cytogenetic response (CCyR) after first line TKI was reported in $26(47.3 \%)$ patients and 5 patients $(9.1 \%)$ had major cytogenetic response. $19(34.5 \%)$ patients had no cytogenetic response, $2(3.6 \%)$ patients had minor cytogenetic response and $3(5.5 \%)$ patients had partial cytogenetic response. In $12(22.6 \%)$ patients, major molecular response (MMR) was obtained. Complete molecular response-CMR was obtained in $3(5.7 \%)$ patients. CHR for second line TKI was $82.4 \%$, and CCyR was $46.2 \%$. Six $(8.1 \%)$ patients died while on study, the major cause of death being disease progression.

T315I mutation detection and correlations with other parameters and outcome

The T315I mutation was detected by ARMS-PCR in three patients $(4.05 \%)$. The presence of the mutation in positive samples was subsequently confirmed by direct sequencing in other centers, abroad.

The median age of patients with the mutation was lower than for negative patients, 


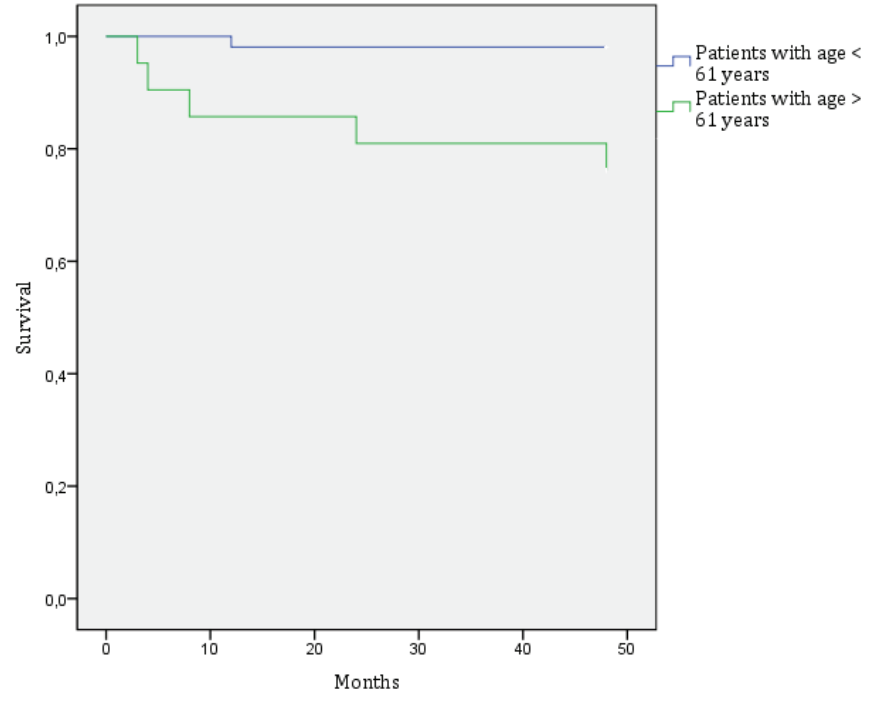

Figure 3. Survival is decreased in patients diagnosed at age $>61$ years

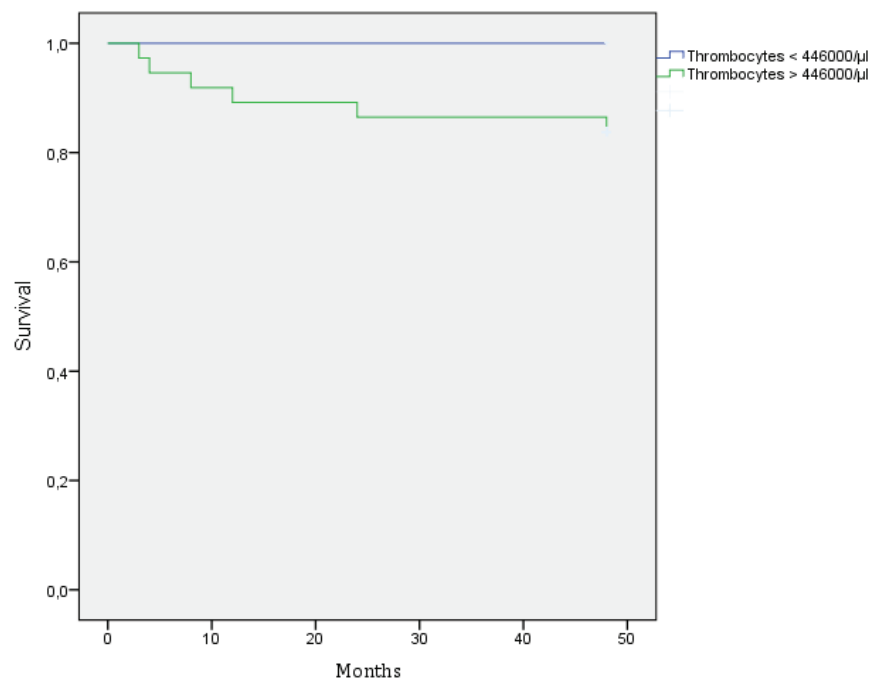

Figure 4. Survival is decreased in patients with Plt $>446 \times 10^{3} / \mu$ l at diagnosis

the result being statistically significant (36 vs. 52.3 years, $\mathrm{p}<0.05)$. An AUROC test to determine the cut-off age under which the probability of T315I mutation increases was applied and a value of 33 years was obtained, with a sensitivity of $66.67 \%$ (CI 95\% 9.4-99.2), a specificity of $88.73 \%$ (CI 95\% 79-95) (p<0.001; Figure 2).
There were no differences regarding the mutation between sexes (test $\chi^{2} ; \mathrm{p}=0.7$ ). Although, patients with T315I mutation tended to have higher LDH (1200 U/L vs. $700 \mathrm{U} / \mathrm{L})$, the differences were not statistically significant (Mann-Whitney test; $\mathrm{p}=0.07$ ). The T315I mutation was detected in both patients with chromosome $\mathrm{Ph}^{1}$ duplication. The patients positive for the T315I mutation had a higher WBC $\left(117.6 \times 10\right.$ vs. $\left.98.1 \times 10^{3} / \mu 1\right)$, Plt $\left(682.3 \times 10\right.$ vs. $\left.490.6 \times 10^{3} / \mu 1\right)$ and lower $\mathrm{Hb}$ (10.9 vs. 11.3) than patients without the mutation but the differences were not statistically significant. There were also no differences in peripheral blood basophil $(\mathrm{p}=0.5)$ and blast percentage $(\mathrm{p}=0.8)$ between patients positive and negative for T315I mutation. Spleen size also did not differ between patients with or without the T315I mutation $(\mathrm{p}=0.7)$.

There were no differences in Sokal score $(\mathrm{p}=0.9)$, Hasford score $(\mathrm{p}=0.1)$ and EUTOS score $(\mathrm{p}=0.9)$ between T315I positive and negative patients.

The hematologic response was not correlated with the mutation. However, in T315I-positive patients neither CCyR nor MMR was obtained. Still, due to the small number of cases no statistically significant correlation was obtained.

We found however a strong correlation between T315I mutation and multiple lines of TKI therapy (Fisher Exact Test; $\mathrm{p}=0.01$ ), all patients positive for the mutation being exposed to several lines of treatment.

Of the 74 patients included in our study, 8 patients progressed to blastic phase $(10.8 \%)$ and 4 patients $(5.4 \%)$ to accelerated phase. All three patients presenting the T315I mutation progressed to accelerated and/or blastic phase. The first T315I patient presented with intermediate Sokal score, was initially treated with interferon, subsequently with imatinib, but had no response to 3 lines of TKIs (IM, dasatinib, nilotinib), progressed to accelerated phase 112 months after diagnosis 


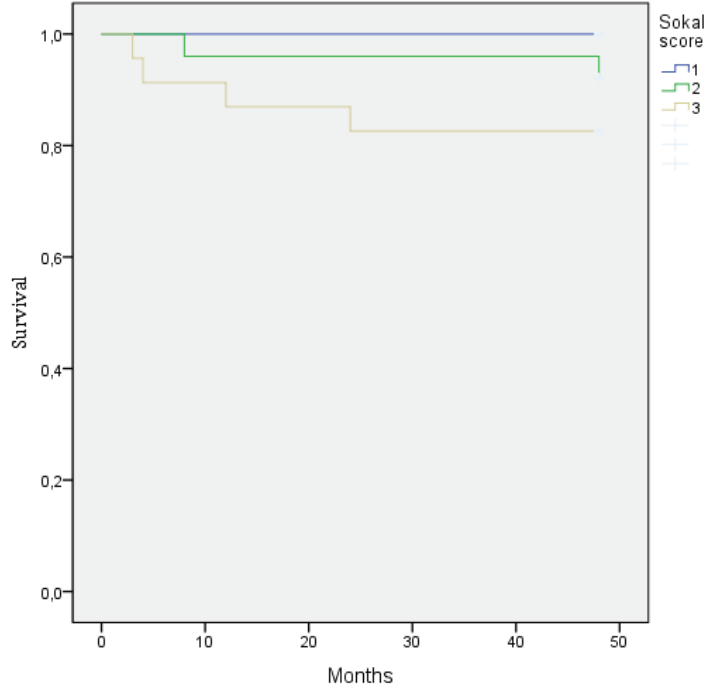

Figure 5. Survival is decreased in patients with Sokal 3 (high)

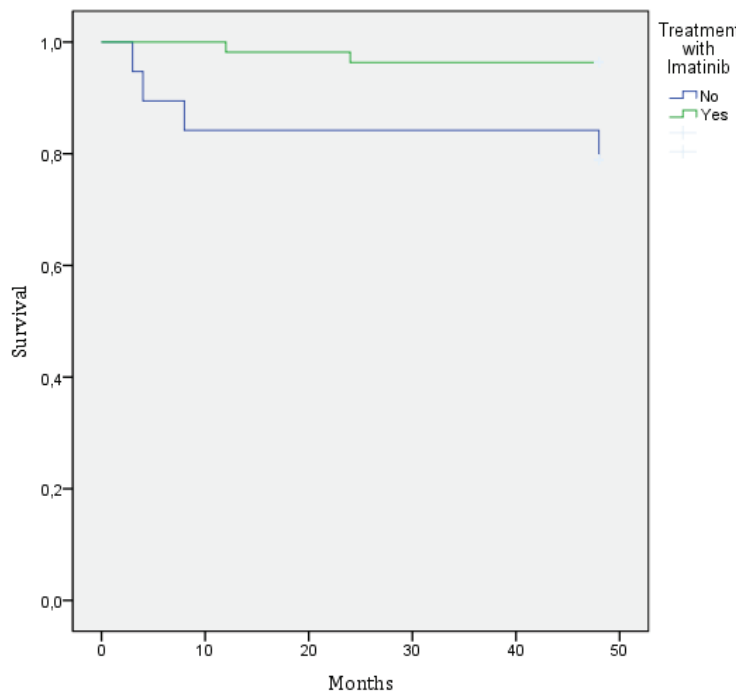

Figure 6. Survival is significantly better in patients treated with first line imatinib mesylate

and at that point the T315I mutation was found to be positive. A treatment with homoarhingtonine was administered, but the patient had no response, progressed shortly afterwards to blastic phase and expired. The second patient, diagnosed with chronic phase CML, high Sokal score, high Hasford score, EUTOS 2 and $\mathrm{Ph}^{1}$ chromosome duplication, progressed to blastic phase shortly after diagnosis, under IM therapy. No response was noted after dasatinib, nilotinib or subsequent IFN association. The T315I mutation was detected 6 months after diagnosis. We opted for aggressive chemotherapy (FLAG protocol) and then allogeneic transplantation from related donor, but the patient expired with non-engraftment probably due to blastic marrow infiltration. The third T315I-positive patient has a disease evolution of 94 months. He presented with $\mathrm{Ph}^{1}$ chromosome duplication. He progressed to accelerated phase during IM therapy and is currently in chronic phase under dasatinib therapy, in CHR but with no cytogenetic or molecular response so far.

As previously stated, six (8.1\%) patients died while on study, the major cause of death being disease progression. Age higher than 61 years at diagnosis was associated with early death ( $\mathrm{p}=0.002$; Figure 3 ). Although survival was better for women than men, the difference was not significant $(\mathrm{p}=0.2)$. WBC and LDH value were not predictive for survival $(\mathrm{p}=0.1)$. Percentages of blasts, basophils and spleen size were not higher in patients who died. Patients with Plt $>446 \times 10^{3} / \mu 1$ had a shorter survival $(\mathrm{p}=0.01$; Figure 4). Higher Sokal and Hasford scores correlated with increased risk of death $(\mathrm{p}=0.03 ;$ Figure 5 , respectively $\mathrm{p}=0.04$ ). However EUTOS scores were not associated with disease evolution in our cohort. The risk of death was significantly reduced in patients treated with IM in first line $(\mathrm{p}=0.01$; Figure 6$)$. The risk of death was significantly increased in patients with no hematologic response to first line TKI $(\mathrm{p}<0.001$; Figure 7). Cytogenetic and molecular responses to first line TKI therapy, hematologic, cytogenetic and molecular responses to second line TKI therapy were not correlated with death risk. 


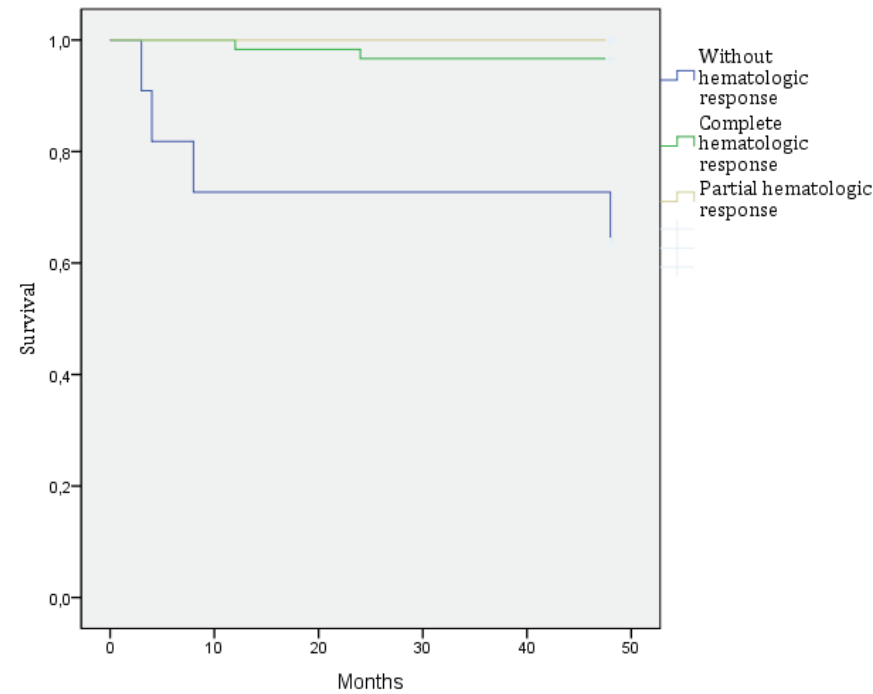

Figure 7. Survival is significantly decreased in patients without hematologic response to first line TKI therapy

\section{Discussion}

The T315I mutation was not detected at diagnosis in our patients. The mutation appeared during TKI treatment in only 3 patients $(4.05 \%)$ which is consistent with data in the literature. Despite the inherent statistical limitations in comparing a group of 3 patients with a group of 71 patients, several aspects concerning the impact of the mutation on disease progression and response to TKI were evident. The presence of the mutation correlated with disease progression in 2 patients (one accelerated phase and one blastic phase) and with lack of response to 2 lines of TKI therapy in the third patient. The T315I mutation was associated with younger age at diagnosis, with multiple lines of TKI therapy due to suboptimal response or progression, the differences being statistically significant. The duration of TKI therapy had no influence on the emergence of the T315I mutation. T315I mutation was correlated with higher WBC and Plt count, lower $\mathrm{Hb}$, higher $\mathrm{LDH}$ value, but the differences was not statistically significant, one important factor in the statistical assessment being the small size of the positive sample. Two patients presented with $\mathrm{Ph}^{1}$ chromosome duplication, considered a negative pro- gnostic factor. Both patients progressed and developed T315I mutation. The hematologic response rate of $90.9 \%$ to first line TKI is similar to rates described in the literature. CCyR (40.9\%) and MMR (22.6\%) rates are inferior to other studies $(1,2)$. It is known that TKI resistance is multifactorial. Unfortunately, we could not determine IM serum levels, hOCT1 serum level as well as other ABL mutations. The EUTOS score was designed to predict cytogenetic response to TKIs. In our study, we did not find a correlation between EUTOS score and cytogenetic response. In fact, the prognostic value of the EUTOS score is controversial, further evaluation being needed (16). A higher rate of progression to accelerated (4 patients) and blastic phases (8 patients) was observed in our patients than described in other studies. It is true that second generation TKIs were not easily available during the study period. Even so, the overall survival was satisfactory with only 6 deaths (8.1\%), confirming the overall progress in CML survival in the TKI era. The risk of death was correlated with younger age at diagnosis, higher Plt count, higher Sokal and Hasford scores, lack of CHR to first line TKI. There are few options currently for patients harboring T315I mutation: allogeneic bone marrow transplantation, omacetaxine, third generation TKI's such as ponatinib. A recently published article by Cortes et al showed that omacetaxine is an alternative treatment for the patients with CML harboring the T315I mutation with rates of $\mathrm{CHR}$ at $77 \%$ and CCyR at $16 \%(17,18)$. Also a recent analysis of a phase I study by Cortes et al demonstrated efficacy of ponatinib for patients with chronic phase CML and T315I mutation $(18,19)$.

Regarding the method used in the detection of the T315I mutation, we believe that the ARMS-PCR technique has a high sensitivity and specificity, is inexpensive and can be used on a regular basis, as a screening test during the treatment of CML patients. However, it has 2 major disadvantages: it allows the analysis of only one known mutation and sometimes, due to difficulties concerning DNA sequence, the mutation 


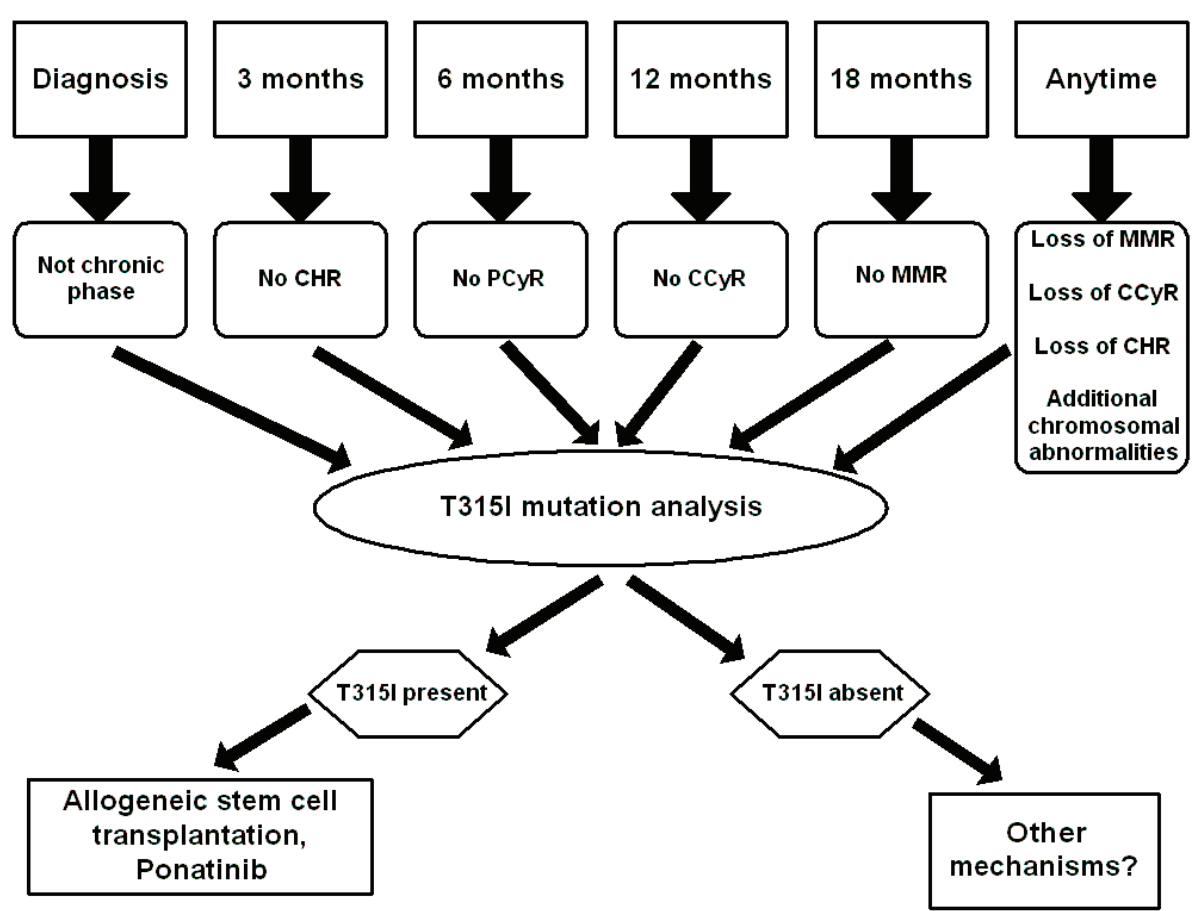

Figure 8. Algorithm for follow-up of CML patients considering T315I mutation analysis

cannot be analyzed. Indeed, the standard method for identifying mutations in the ABL kinase domain, as recommended by ELN (20) is direct sequencing. However, direct sequencing is not currently available in our center.

Based on our data we propose an algorithm on the follow-up of CML patients, taking into account the T315I mutation (Figure 8). According to this algorithm, T315I evaluation should be done in case of suboptimal or loss of response to TKI treatment or progression. T315I positive patients should be offered allogeneic stem cell transplantation as soon as possible, or enrolled in clinical trials with new agents such as ponatinib or other new agents (Aurora kinase inhibitors, etc.).

\section{Conclusions}

To our knowledge, this is the first study performed in Romania dedicated to the prevalence of T315I mutation in chronic phase CML patients treated with TKI. Our study confirms that T315I mutation correlates with negative prognostic factors: duplication of $\mathrm{Ph}^{1}$ chromosome, young age at diagnosis (33 years in our patients), multiple TKI therapies. The survival of patients bearing the mutation is short and patients bearing the mutation should be offered alternative options as soon as possible. ARMS-PCR is a sensitive, useful, easy to use method for the detection of T315I mutation in chronic phase CML patients. Mutational analysis is not necessary on a regular basis, but is mandatory in case of suboptimal response, loss of response or progression.

\section{References}

1. Lichtman LA, Liesveld JL. CML and related disorders, in Williams Hematology, McGraw Hill 8th edition, 1085-1124.

2. Petrov L, Cucuianu A, Bojan A, Urian L. Leucemia granulocitara cronica. In "Hematologie Clinica". Casa Cartii de Stiinta, Cluj-Napoca, 2009: 45-63

3. Apperley JF. Mechanism of resistance to imatinib in chronic myeloid leukemia. Lancet Oncol, 2007, 8:10181029 
4. Quintas-Guardama A, Kantarjian H, Cortes J. Mechanism of primary and secondary resistance to imatinib in chronic myeloid leukemia. Cancer Control, 2009, 16: 122131.

5. Bixby D, Talpaz M. Mechanism of resistance to tyrosine kinase inhibitors in chronic myeloid leukemia and recent therapeutic strategies to overcome resistance. Hematology 2009, 1: 461-476

6. Nicolini FE, Corm S, Le QH, Sorel N, Hayette S, Bories $\mathrm{D}$ et al. Mutation status and clinical outcome of 89 imatinib mesylate- resistant chronic myelogenous leukemia patients: a retrospective analysis from the French intergroup of CML. Leukemia 2006, 20: 1061-1066

7. Nicolini FE, Hayette S, Corm S, Bachy E, Bories D, Tulliez $\mathrm{M}$ et al. Clinical outcome of 27 imatinib mesylate resistant chronic myelogenous leukemia patients harboring T315I BCR-ABL mutation. The Hematology Journal 2007, 92: 1238-1241

8. Nicolini FE, Mauro MJ, Martinelli G, Kim DW, Soverini S, Muller MC et al. Epidemiologic study on survival of chronic myeloid leukemia and $\mathrm{Ph}(+)$ acute lymphoblastic leukemia patients with BCR-ABL T315I mutation. Blood, 2009, 114: 5271-5278.

9. Hughes T, Saglio G, Branford S, Soverini S, Kim DW, Muller MC et al. Impact of baseline BCR-ABL mutations on response to nilotinib in patients with chronic myeloid leukemia in chronic phase. J Clin Oncol, 2009, 27: 4204-4210

10. Muller Mc, Cortes JE, Kim DW, Druker BJ, Erben $\mathrm{P}$, Pasquini R et al. Dasatinib treatment of chronic phase chronic myeloid leukemia, analysis of responses according to preexisting BCR-ABL mutations. Blood, 2009, 114:4944-4953

11. Goldman JM. How I treat chronic myeloid leukemia in the imatinib era. Blood, 2007, 110: 2828-37

12. Roche-Lestienne C, Soenen-Cornu V, GrardelDuflos N, Laï JL, Philippe N, Facon T et all. Several types of mutations of the Abl gene can be found in chronic myeloid leukemia patients resistant to STI571, and they can pre-exist to the onset of treatment. Blood, 2002, 100:10141018

13. Khorashad JS, Thelwell N, Milojkovic D, Marin D, Watson JA, Goldman JM, Apperley JF et al. A new rapid and sensitive assay for detecting the chronic myeloid leukemia T315I BCR-ABL kinase domain mutation in chronic myeloid leukemia. J Clin Pathol. 2008, 61, 863-865

14. Y M Dennis Lo. The amplification refractory mutation system. Methods in Molecular Medicine, 1998, 16: 61-69

15. Dima D, Trifa AP, Cucuianu A, Popp RA, Patiu M, Petrov L. Monitoring T315I mutation in chronic myeloid leukemia by amplification refractory mutation system PCR. Rev Rom de Med de Lab, 2008, 13:17-20

16. Marin D, Ibrahim Amr R, Goldman JM. European treatment and outcome study (EUTOS) score for chronic myeloid leukemia still requires more confirmation. J Clin Oncol, 2011, 29: 3944-3945

17. Cortes J, Lipton JH, Rea D, Diqumarti R, Chuah C, Nanda $\mathrm{N}$ et al. Phase 2 study of subcutaneous omacetaxine mepesuccinate after TKI failure in patients with CML with T315I mutation. Blood, 2012, 120:2573-2580

18. Wei G, Rafiyath S and Liu D. First line treatment of chronic myeloid leukemia: dasatinib, nilotinib or imatinib. J Hematol Oncol, 2010, 3: 47-52

19. Cortes JE, Kantarjian H, Shah NP, Bixby D, Mauro MJ, Flinn I et al. Ponatinib in refractory Philadelphia chromosome-positive leukemias. N Eng J Med, 2012, 367:2075-88

20. Soverini S, Hochhaus A, Nicolini FE, Gruber F, Lange T, Saglio G, et al. BCR-ABL kinase domain mutation analysis in chronic myeloid leukemia patients treated with tyrosine kinase inhibitors: recommendations from an expert panel on behalf of European LeukemiaNet. Blood, 2011, 118:1208-1215 